\title{
Overcoming seed dormancy and evaluation of viability in Leucaena leucocephala
}

\author{
Regina Soares Bichoff ${ }^{1}$, Amanda Nogueira de Albuquerque ${ }^{1}$, Daiane de Cinque Mariano ${ }^{2}$, Ricardo \\ Shigueru Okumura ${ }^{2 *}$, Rudson Silva Oliveira ${ }^{2}$, Cândido Ferreira de Oliveira Neto ${ }^{2}$, Ismael de Jesus Matos \\ Viégas ${ }^{2}$, Augusto José Silva Pedroso ${ }^{3}$, José Darlon Nascimento Alves ${ }^{2}$, Diego Correia Sodré ${ }^{2}$, Gislayne \\ Farias Valente ${ }^{2}$
}

\author{
${ }^{1}$ Department of Agronomy, University of State of Mato Grosso, Tangará da Serra city, Highway MT 358, CEP 78300- \\ 000, Brazil \\ ${ }^{2}$ Institute of Agrarian Sciences, Federal Rural University of Amazônia, Parauapebas city, Highway PA 275, CEP \\ 68515-000, Brazil \\ ${ }^{3}$ Department of Agronomy, Federal Institute of Pará, Castanhal city, Highway BR 316, CEP 68740-970, Brazil
}

"Corresponding author: ricardo.okumura@ufra.edu.br

\begin{abstract}
Leucaena leucocephala is an arboreal legume with many applications in agriculture (forage, wood production, charcoal, soil improvement, shading, windbreak, and hedge). Its seeds show dormancy, which is caused by physical blockade through resistant and impermeable integument. The aims of this study were to evaluate and determine efficient methods for overcoming dormancy in Leucaena leucocephala seeds. The experiment was carried out in Tangará da Serra city, Brazil, adopting a completely randomized design, with four replications. The treatments consisted of no scarification $\left(T_{0}\right)$, scarification with sandpaper $\left(T_{1}\right)$, immersion in concentrated $\mathrm{H}_{2} \mathrm{SO}_{4}$ for $5 \mathrm{~min}\left(\mathrm{~T}_{2}\right), 10^{\prime}\left(\mathrm{T}_{3}\right), 15^{\prime}\left(\mathrm{T}_{4}\right)$, and $20^{\prime}\left(\mathrm{T}_{5}\right)$, and immersion in water at $80^{\circ} \mathrm{C}$ for $5^{\prime}\left(\mathrm{T}_{6}\right), 10^{\prime}\left(\mathrm{T}_{7}\right), 15^{\prime}\left(\mathrm{T}_{8}\right)$ and $20^{\prime}$ $\left(T_{9}\right)$. The seeds were placed in germination chamber at a temperature of $25^{\circ} \mathrm{C}$ and photoperiod of 12 hours day/night over a period of 10 days, for all treatments, using 50 seeds per replicate. The experimental data were submitted to analysis of variance (type I error) by $\mathrm{F}$ test $(p<0.05)$ with comparison of averages performed by Tukey test $(p<0.05)$. The treatment that showed best efficiency in overcoming seed dormancy was immersion in concentrated $\mathrm{H}_{2} \mathrm{SO}_{4}$ (density of 1.84 and purity of $95 \%$ ) for 20 min, with $93.0 \%$ of viable seed germinated. Immersion of seeds in water at $80 \circ \mathrm{C}$ for $20 \mathrm{~min}$ ( $0.0 \%$ seed germination) showed lowest efficiency in overcoming dormancy of Leucaena leucocephala seeds. It was concluded that treatment with immersion in concentrated $\mathrm{H}_{2} \mathrm{SO}_{4}$ for $20 \mathrm{~min}$ is the most efficient in overcoming dormancy of Leucaena leucocephala seeds, showing higher values of first germination count, germination percentage, germination speed index and average time of germination.
\end{abstract}

Keywords: Scarification with sandpaper, immersion in concentrated $\mathrm{H}_{2} \mathrm{SO}_{4}$, immersion in water at $80^{\circ} \mathrm{C}$, Leucaena leucocephala seed, dormancy overcoming.

Abbreviations: $\mathrm{H}_{2} \mathrm{SO}_{4}$ sulfuric acid, DAS_day after sowing, GSI_germination speed index, ATG_average time of germination, FGC_first germination count, GP_germination percentage.

Introduction

Leucaena leucocephala is an arboreal legume which has a very diversified use, highlighting in reforestation of degraded areas for erosion control. Currently, it is also used for animal feed, green manuring, fence posts, poles, cellulose, and plywood (Osechas et al., 2008). The presence of legumes in tropical grass pastures improves ruminant nutrition due to higher protein contents for development of microorganisms that digest forage (Valente et al., 2016). The tropical legume grasses have shown good results on production of goats (Rubanza et al., 2007), sheep (Santana et al., 2014), buffaloes (Kang et al., 2012) and cattle (Díaz et al., 2009).

In Brazil, the species is popularly known as leucaena (Fonseca and Jacobi, 2011), and is indicated as a good candidate for inclusion in agroforestry systems (Pereyra et al., 2015) due to its rapid growth and high nutritional value of minerals and proteins (Crawford et al., 2015), mainly in semi-arid regions (Walker, 2012). This legume has shown good general characteristics such as high seed production, which facilitates its propagation, if the dormancy of seeds be overcome (Drumond and Ribaski, 2010). The physical impediment such as dormancy increases survival of species, which allows seeds to maintain viability for a longer period of time (Nesi et al., 2016), as well as production of seedlings and obtaining plants with standard development (Drumond and Ribaski, 2010). In legume seeds, the dormancy is promoted by resistant tegument and impermeability to water, preventing water and gas exchanges. It suppresses seed imbibition and absorption of oxygen by embryo (Drumond and Ribaski, 2010). The sowing performance without physical dormancy breaking processes results in slow and irregular emergence, with direct effect on seedling development (Martins and Lago, 1996). According to Teles et 
al. (2000) and Paulino et al. (2004) sowing the Leucaena leucocephala seeds without overcoming dormancy resulted in a germination index less than $50 \%$, causing slow and irregular emergence with negative consequence on plant density, as well as to promote weed infestation. Therefore, adoption of pre-germination treatments to overcome dormancy is important to accelerate and standardize seed germination (Dapont et al., 2014; Pereira et al., 2013).

The most adopted methods to overcome impermeability to water of legume seeds are through: mechanical scarification, using abrasive surfaces (Mantoan et al., 2012); chemical treatment with use of sulfuric or hydrochloric acids, immersion in acidic substances (Rebouças et al., 2012); and immersion in hot water (Araújo et al., 2012). Thus, research on seed dormancy break provides a fundamental background for scientific communities. Furthermore, the knowledge of seed germination is vital to use in reforestation programs. In addition, genetic diversity between species has promoted greater concern of seed researchers and analysts, in conducting studies that provide information on seed quality, mainly for standardization, improvement and establishment of efficient methods to overcome the seeds.

There is scarcity of information about the characteristics of Leucaena leucocephala seeds such as thickness and hardness of tegument. Therefore, this study intends to fill some doubts in knowledge for seedlings production. The present study has chosen practical and cheap methods for overcoming dormancy that can be used in practice by farmers. Thus, the aims were to evaluate and identify methodologies for overcoming dormancy and to promote the germination in Leucaena leucocephala seeds for seedlings production.

\section{Results and discussion}

\section{Germination of Leucaena leucocephala}

The results of first germination count (FGC), germination percentage (GP), germination speed index (GSI) and average time of germination (ATG) are shown in Table 1. In first germination count (FGC), seeds were chemically scarified by immersion in $\mathrm{H}_{2} \mathrm{SO}_{4}$ for 20 min $\left(T_{5}\right)$. The $\left(T_{5}\right)$ obtained best results with $88.0 \%$ seed germination rate possibly due to breaking of seed integument. The treatments with water immersion at $80^{\circ} \mathrm{C}$ for $5^{\prime}\left(\mathrm{T}_{6}\right), 10^{\prime}\left(\mathrm{T}_{7}\right), 15^{\prime}\left(\mathrm{T}_{8}\right)$, and $20^{\prime}\left(\mathrm{T}_{9}\right)$ caused less beneficial results, lower than scarification $\left(T_{1}\right)$ and chemical treatment $\left(T_{2}, T_{3}, T_{4}\right.$, and $\left.T_{5}\right)$, being statistically equal to control treatment $\left(T_{0}\right)$.

Oliveira, (2009) studied first count of germination in Leucaena leucocephala and observed better results with immersion of seeds in $\mathrm{H}_{2} \mathrm{SO}_{4}$, compared to treatments with immersion in hot water. The sanding scarification resulted in lower value (62.5\%) than described by Cardoso et al. (2012), which recorded value of $97.0 \%$ for first count of germination.

For variable germination percentage (GP), most promising treatments were: $T_{1}$ (scarification with sandpaper), $T_{4}$ (immersion in $\mathrm{H}_{2} \mathrm{SO}_{4}$ for ${ }^{\prime} 5^{\prime}$ ), and $\mathrm{T}_{5}$ (immersion in $\mathrm{H}_{2} \mathrm{SO}_{4}$ for 20 ') with $82.5 \%, 75.0 \%$, and $93.0 \%$ of germinated normal seedlings, respectively (Table 1 ). The seed immersion in water at $80^{\circ} \mathrm{C}$ for $10^{\prime}\left(T_{7}\right)$, and $15^{\prime}\left(T_{8}\right)$ did not produce satisfactory results, having a low number of germinated seeds, statistically equal to control $\left(\mathrm{T}_{0}\right)$.
The results (Table 1 ) disagrees with those obtained by Passos et al. (1988), whose reported that immersion in hot water was efficient to overcome dormancy. In our study, it was evident that treatment with immersion at $80^{\circ} \mathrm{C}$ water for period of $20^{\prime}\left(T_{9}\right)$, produced no seed germination. Perhaps, period and time of treatment with hot water was long enough to cause death of the seed embryo (Xavier et al., 2012).

Alves et al. (2004) and Paulino et al. (2004) observed values of $30 \%$ and $70 \%$ seed emergence in Bauhinia divaricata and Leucaena leucocephala, respectively, subjected to treatment with immersion in water at $80^{\circ} \mathrm{C}$

Souza et al. (2007) observed higher efficiency associated with acid scarification compared to warm water in Leucaena leucocephala seeds, especially in seeds exposed to hot water for a longer period. In this case, exposure period has possibly impaired viability of embryo and reduced germination around $30 \%$, compared to the best treatment $\left(\mathrm{H}_{2} \mathrm{SO}_{4}\right)$. In a study developed by Teles et al. (2000), they reported seed germination of $97.3 \%$ treated with $\mathrm{H}_{2} \mathrm{SO}_{4}$ for $10^{\prime}, 15^{\prime}$, and 20', confirming efficiency of method in overcoming dormancy of Leucaena leucocephala seeds.

The application of treatments to overcome seed dormancy does not usually damage embryos if be performed efficiently. Because this procedure is normally promoted in nature by open cracks in bark by action of microorganisms, fungi or acids of soil (Freire et al., 2016). According to Santos et al. (2011) and Costa et al. (2010) as a result of variation in composition and thickness of integuments of each species, it is necessary to carry out studies on type of treatment and time of seed immersion in acid or water to overcome seed dormancy.

From information shown in Table 1 , we observe that germination speed index (GSI) was higher than other treatments using immersion in $\mathrm{H}_{2} \mathrm{SO}_{4}$ for $20^{\prime}$, with a value of $89.3 \%$. In contrast, the germination speed index subjected to treatments with hot water for $5^{\prime}(18.7 \%), 10^{\prime}(16.9 \%)$, and $15^{\prime}(12.6 \%)$ were lower, only a bit higher than control (3.7\%). Similar results were obtained by Oliveira (2009) and Passos et al. (1988), in which overcoming dormancy with $\mathrm{H}_{2} \mathrm{SO}_{4}$ provided better germination speed index for Leucaena leucocephala seeds.

For variable average time of germination (ATG), sandpaper scarification $\left(\mathrm{T}_{1}\right)$, and immersion in $\mathrm{H}_{2} \mathrm{SO}_{4}$ treatments for $10^{\prime}$ $\left(T_{3}\right), 15^{\prime}\left(T_{4}\right)$, and $20^{\prime}\left(T_{5}\right)$ obtained values of $6.1,6.3,6.2$, and 6.0 days, respectively, showing no statistical difference (Table 1). Treatment with $T_{8}$ caused a time of 8.4 days for germination of seeds (Table 1).

According to Oliveira (2009), Leucaena leucocephala seeds treated with $\mathrm{H}_{2} \mathrm{SO}_{4}$ revealed best results for average time of germination compared to hot water treatment, due to high temperature used to negatively influence physiological mechanisms of seeds and viability of embryo, delaying germination and inducing seed inactivity.

\section{Material and methods}

\section{Plant materials and experimental site}

Leucaena (Leucaena leucocephala) seeds were collected in April 2013 from trees showing fully mature pods, located at Universidade do Estado de Mato Grosso (UNEMAT), Tangará 
Table 1. Influence of methods to overcome dormancy in germination process of Leucaena leucocephala seeds.

\begin{tabular}{|c|c|c|c|c|}
\hline Treatment & FCG & GP & GSI & ATG \\
\hline & \multicolumn{3}{|c|}{ 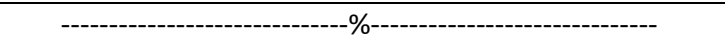 } & days \\
\hline $\mathrm{T}_{0}^{+}$ & $4.0 e^{*}$ & $4.5 f g$ & $3.7 f$ & $7.0 \mathrm{c}$ \\
\hline $\mathrm{T}_{1}$ & $62.5 b$ & $82.5 \mathrm{ab}$ & $76.3 b$ & $6.1 d$ \\
\hline $\mathrm{T}_{2}$ & $24.5 d$ & $34.0 d$ & $21.2 d$ & $7.0 \mathrm{c}$ \\
\hline $\mathrm{T}_{3}$ & $24.0 d$ & $62.5 c$ & $63.5 c$ & $6.3 d$ \\
\hline $\mathrm{T}_{4}$ & $48.5 c$ & $75.0 \mathrm{~b}$ & $70.1 \mathrm{bc}$ & $6.2 \mathrm{~d}$ \\
\hline $\mathrm{T}_{5}$ & $88.0 \mathrm{a}$ & $93.0 \mathrm{a}$ & $89.3 a$ & $6.0 \mathrm{~d}$ \\
\hline $\mathrm{T}_{6}$ & $10.5 \mathrm{e}$ & 24.0de & $18.7 \mathrm{de}$ & $7.6 b$ \\
\hline $\mathrm{T}_{7}$ & $8.5 e$ & 15.0ef & $16.9 \mathrm{de}$ & $7.8 b$ \\
\hline $\mathrm{T}_{8}$ & $1.0 \mathrm{e}$ & 12.0efg & $12.6 \mathrm{e}$ & $8.4 a$ \\
\hline $\mathrm{T}_{9}$ & $0.0 \mathrm{e}$ & $0.0 \mathrm{~g}$ & $0.0 f$ & $0.0 \mathrm{e}$ \\
\hline CV(\%) & 17.78 & 16.97 & 9.42 & 3.26 \\
\hline
\end{tabular}

* Means followed by the same letter in the column do not differ by the Tukey test at $5 \%$ probability. First count of germination (FCG), germination percentage (GP), germination speed index (GSI), and average time of germination (ATG). $+\mathrm{T}_{0}-$ no scarification (control); $\mathrm{T}_{1}-$ scarification with sandpaper; $\mathrm{T}_{2}-\mathrm{immersion}$ in $\mathrm{H}_{2} \mathrm{SO}_{4}$ for $5^{\prime}$; $\mathrm{T}_{3}$ - immersion in $\mathrm{H}_{2} \mathrm{SO}_{4}$ for $10^{\prime} ; \mathrm{T}_{4}$ - immersion in $\mathrm{H}_{2} \mathrm{SO}_{4}$ for $15^{\prime} ; \mathrm{T}_{5}$-immersion in $\mathrm{H}_{2} \mathrm{SO}_{4}$ for $20^{\prime} ; \mathrm{T}_{6}-$ immersion in water at $80^{\circ} \mathrm{C}$ for $5^{\prime} ; \mathrm{T}_{7}-$ immersion in water at $80^{\circ} \mathrm{C}$ for $10^{\prime} ; \mathrm{T}_{8}$-immersion in water at $80^{\circ} \mathrm{C}$ for $15^{\prime} ; \mathrm{T}_{9}-$ immersion in water at $80^{\circ} \mathrm{C}$ for $20^{\prime}$.

da Serra city, State of Pará, Brazil (14³7'10' S e $57^{\circ} 29^{\prime} 09^{\prime \prime}$ W). After collection, seeds were dried in shade for a period of one week for later layout of experiment, being conducted in Phytopathology Laboratory of UNEMAT.

\section{Dormancy breaking treatments}

The experimental design was a completely randomized design with four replications, consisting of the following treatments:

$\mathrm{T}_{0}$ : without scarification;

$\mathrm{T}_{1}$ : scarification with sandpaper;

$\mathrm{T}_{2}$ : immersion in concentrated $\mathrm{H}_{2} \mathrm{SO}_{4}$ (density of 1.84 and purity of $95 \%$ ) for 5 ;

$\mathrm{T}_{3}$ : immersion in concentrated $\mathrm{H}_{2} \mathrm{SO}_{4}$ for $10^{\prime}$;

$\mathrm{T}_{4}$ : immersion in concentrated $\mathrm{H}_{2} \mathrm{SO}_{4}$ for $15^{\prime}$;

$\mathrm{T}_{5}$ : immersion in concentrated $\mathrm{H}_{2} \mathrm{SO}_{4}$ for 20';

$\mathrm{T}_{6}$ : immersion in $\mathrm{H}_{2} \mathrm{O}$ at $80^{\circ} \mathrm{C}$ for $5^{\prime}$;

$\mathrm{T}_{7}$ : immersion in $\mathrm{H}_{2} \mathrm{O}$ at $80^{\circ} \mathrm{C}$ for $10^{\prime}$;

$\mathrm{T}_{8}$ : immersion in $\mathrm{H}_{2} \mathrm{O}$ at $80^{\circ} \mathrm{C}$ for $15^{\prime}$;

$\mathrm{T}_{9}$ : immersion in $\mathrm{H}_{2} \mathrm{O}$ at $80^{\circ} \mathrm{C}$ for $20^{\prime}$.

\section{Experiment information}

A common sandpaper type was used for scarification treatment with sandpaper. Seeds were sanded manually on both sides, without damaging the embryo (Cardoso et al., 2012), while, immersion treatment in $\mathrm{H}_{2} \mathrm{SO}_{4}$ was used as proposed by Xavier et al. (2012), in which seeds were treated with $\mathrm{H}_{2} \mathrm{SO}_{4}$ (density of 1.84 and purity of $95 \%$ ) for $5^{\prime}, 10^{\prime}, 15^{\prime}$ and $20^{\prime}(\mathrm{min})$, respectively, then, washed in running water for $5^{\prime}$ for removal of acid residues and after drying on paper towels (Nautiyal et al., 2014).

In hot water treatment at $80^{\circ} \mathrm{C}$, seeds were immersed in beakers with water, and remained in water bath equipment until their treatment periods were reached, which were $5^{\prime}$, $10^{\prime}, 15^{\prime}$, and 20'. Afterwards, seeds were pulled out from heat source, remaining in water until reaching ambient temperature (Pacheco et al., 2014).

To evaluate influence of treatments on seed germination, four replicates of 50 seeds of each were disinfested by immersion in sodium hypochlorite $(2 \%)$ for 51 , washed in running water and placed to dry on germitest paper in the shade. The seeds were distributed on a paper substrate in the form of rolls, previously moistened with distilled water, in an amount equivalent to 2.5 times the weight of dry paper (Paiva et al., 2016; Zimmer et al., 2016). Then, paper was organized in roll form and incubated in germination chamber (Biochemical Oxygen Demand - B.O.D.) at a constant temperature of $30^{\circ} \mathrm{C}$, with photoperiod of 12 hours for 10 day (Brasil, 2009).

\section{Evaluated characteristics}

The germination was evaluated daily, starting on the $4^{\text {th }}$ day after sowing (DAS) and finished in $10^{\text {th }}$ DAS, through percentage of normal seedlings, being considered germinated seeds that showed process of emission of essential structures of embryo.

The germination speed index (GSI) was expressed as a percentage, were calculated as outlined below (Vange et al., 2016):

Being:

$$
\mathrm{GSI}=\frac{\mathrm{G}_{1}}{\mathrm{~N}_{1}}+\frac{\mathrm{G}_{2}}{\mathrm{~N}_{2}}+\cdots+\frac{\mathrm{G}_{\mathrm{n}}}{\mathrm{N}_{\mathrm{n}}}
$$

$G_{1}, G_{2}, G_{n}=$ number of seedlings germinated in first, second, until last count;

$N_{1}, N_{2}, N_{n}=$ number of days after sowing from first, second, to last count.

The average time of germination (ATG) was obtained using the formula, in which results expressed in days (Yu et al., 2008):

Being:

$$
A T G=\frac{G_{1} \times T_{1}+G_{2} \times T_{2}+\cdots+G_{n} \times T_{n}}{G_{1}+G_{2}+\cdots+G_{n}}
$$

$\mathrm{G}_{1}, \mathrm{G}_{2}, \mathrm{G}_{\mathrm{n}}=$ number of seedlings germinated in first, second, until last count;

$T_{1}, T_{2}, T_{n}=$ number of days after sowing from first, second, to last count.

\section{Statistical analysis}

Initially, the experimental data were submitted to the analysis to test the normality and homogeneity of variance. Then treatment means were submitted to analysis of variance (type I error) by F-test $(p<0.05)$ with comparison of 
averages performed by Tukey test at $5 \%$ of probability, using SISVAR version 5.3 software (Ferreira, 2011).

\section{Conclusion}

The treatment of immersion in $\mathrm{H}_{2} \mathrm{SO}_{4}$ for 20 min is the most efficient in overcoming dormancy of Leucaena leucocephala seeds, showing higher values of first germination count, germination percentage, germination speed index and average time of germination. The immersion of Leucaena leucocephala seeds in water at a temperature of $80^{\circ} \mathrm{C}$ does not promote overcoming of dormancy efficiently because causes inactivity in embryo of Leucaena leucocephala.

\section{Acknowledgements}

The authors are grateful to the Grupo de Estudos de Biodiversidade em Plantas Superiores of Universidade Federal Rural da Amazônia (UFRA) and Ciência, Inovação, Tecnologia e Manejo Aplicados aos Sistemas Agrícolas e Florestais Amazônicos (Research Group/UFRA) for the collaborations of researchers.

\section{References}

Alves AU, Dornelas CSM, Bruno RLA, Andrade LA, Alves EU (2004) Overcoming dormancy of Bauhinia divaricata L. seeds. Acta Bot Bras. 18: 871-879.

Araújo TV, Joaquim WM, Barja PR (2012) Techniques to break dormancy and study of organic substrates for production of leucena seedlings. Rev Univap. 18: 89-100.

Brasil (2009) Regras para Análise de Sementes. Brasília, SNDA/DNDV/CLAV. 399p.

Cardoso EA, Alves AU, Cavalcante IHL, Farias SGG, Santiago FEM (2012) Methods for overcoming dormancy in leucena seeds. Rev Ciênc Agrárias. 55: 220-224.

Costa PA, Lima ALS, Zanella F, Freitas H (2010) Overcoming seed dormancy in Adenanthera pavonina L. Pesq Agropec Trop. 40: 83-88.

Crawford G, Puschner B, Affolter V, Stalis I, Davidson A, Baker T, Tahara J, Jolly A, Ostapak S (2015) Systemic effects of Leucaena leucocephala ingestion on ringtailed lemurs (Lemur catta) at Berenty Reserve, Madagascar. Am J Primatol. 77: 633-641.

Dapont EC, Silva JB, Oliveira JD, Alves CZ, Dutra AS (2014) Methods of accelerating and standardizing the emergence of seedlings in Schizolobium amazonicum. Rev Ciênc Agron. 45: 598-605.

Díaz A, Castillo E, Martín PC, Hernández JL (2009) Ceba de toros mestizos lecheros, en silvopastoreo con leucaena, acceso a banco de biomasa y suplemento activador del rumen. Rev Cubana Cienc Agric. 43: 235-238.

Drumond MA, Ribaski J (2010) Leucena (Leucaena leucocephala): Leguminosa de uso múltiplo para o semiárido brasileiro. Colombo, Embrapa Floresta. 8p.

Ferreira DF (2011) Sisvar: A computer statistical analysis system. Ciênc Agrotec. 35: 1039-1042.

Fonseca NG, Jacobi CM (2011) Desempenho germinativo da invasora Leucaena leucocephala (Lam.) de Wit. e comparação com Caesalpinia ferrea Mart. ex Tul. e Caesalpinia pulcherrima (L.) Sw. (Fabaceae). Acta Bot Brasilica. 25: 191-197.
Freire JM, Ataíde DHS, Rouws JRC (2016) Dormancy breaking of Albizia pedicellaris (DC.) L. seeds. Floresta Ambient. 23: 251-257.

Kang S, Wanapat M, Pakdee P, Pilajun R, Cherdthong A (2012) Effects of energy level and Leucaena leucocephala leaf meal as a protein source on rumen fermentation efficiency and digestibility in swamp buffalo. Anim Feed Sci Technol. 174: 131-139.

Mantoan P, Souza-Leal T, Pessa H, Marteline MA, PedrosoDe-Moraes C (2012) Escarificação mecânica e química na superação de dormência de Adenanthera pavonina L. (Fabaceae: Mimosoideae). Sci Plena. 8: 1-8.

Martins L, Lago AA (1996) Germinação e viabilidade de sementes de Brachiaria brizantha (Hochst. Ex A. Rich.) durante o armazenamento. Rev Bras Sementes. 18: 262266.

Nautiyal M, Bahuguna A, Chauhan JS, Singh B (2014) Effect of some pre-sowing scarification treatment on water uptake and germination of Abrus precatorius L. (Ratti). Res J Seed Sci. 7: 14-20.

Nesi CN, Arruda GOSF, Menegatti A (2016) Dormancy overcoming in Jatobá seeds assessed by survival analysis. Rev Ciênc Agrovet. 15: 42-49.

Oliveira AB (2009) Influence of treatments pre-germinatives, temperature and luminosity in germination of leucena seeds (Leucaena leucocephala (Lam.) de Wit.), cunningham variety. Rev Caatinga. 22: 132-138.

Osechas D, Becerra L, Rodriguez I (2008) Uso de Leucaena leucocephala como recurso forrageiro em fincas doble propósito Del estado Trujillo, Venezuela. Agric Andina. 14: 49-58.

Pacheco MV, Araújo FS, Ferrari CS, Bruno RLA (2014) Germination of Combretum leprosum Mart. seeds. Rev Caatinga. 27: 154-162.

Paiva EP, Sá FVS, Torres SB, Nogueira NW, Freitas RMO, Almeida JPN, Leite MS (2016) Germination of seeds of Aspidosperma pyrifolium Mart. Int J Curr Res. 8: 3918339187.

Passos AM, Lima T, Albuquerque JL (1988) Quebra de dormência em sementes de leucena. Rev Bras Sementes. 10: 97-102.

Paulino VT, Freitas JCT, Roberto Junior C, Dalle Vedove DJF, Souza CFJ, Natal V (2004) Escarificação de sementes de leucena (Leucaena leucocephala (lam.) De wit) cultivares cunnighan e piracicaba. Rev Cien Eletrônica Agron. 1: 1-4.

Pereira SR, Laura VA, Souza ALT (2013) Seed dormancy overcoming as a strategy for forest restoration in tropical pasture. Pesq Agropec Bras. 48: 148-156.

Pereyra G, Hartmann H, Michalzik B, Ziegler W, Trumbore S (2015) Influence of rhizobia inoculation on biomass gain and tissue nitrogen content of Leucaena leucocephala seedling under drought. Forests. 6: 3686-3703.

Rebouças ACMN, Matos VP, Ferreira RLC, Sena LHM, Sales AGFA, Ferreira EGBS (2012) Methods for overcoming dormancy of quixabeira seeds (Sideroxylon obtusifolium (Roem. \& Schult.) T. D. Penn.). Ci FI. 22: 183-192.

Rubanza CDK, Shemb MN, Bakengesa SS, Ichinohe T, Fujihara T (2007) Effects of Acacia nilotica, A. polyacantha and Leucaena leucocephala leaf meal supplementation on performance of Small East African goats fed native pasture hay basal forages. Small Rumin Res. 70: 165-173.

Santana YAG, Alves AA, Oliveira MEO, Moreira Filho MAM, Cerqueira Neto CF (2014) Nutritive value of sheep diets 
made up of hay from Tifton 85 grass and leucaena. Rev Ciênc Agron. 45: 387-392.

Santos ALF, Freire JM, Piña-Rodrigues FCM (2011) Avaliação de métodos para superação de dormência de sementes de leguminosas arbóreas utilizadas na recuperação de áreas degradadas. Seropédica, Embrapa Agrobiologia. 32p.

Souza ERB, Zago R, Garcia J, Farias JG, Carvalho SEM, Barroso MR (2007) Effects of tegument scarification methods on Leucaena diversifolia L. seeds. Pesq Agropec Trop. 37: 142146.

Teles MM, Alves AA, Oliveira JCG, Bezerra AME (2000) Procedure for dormancy breakage in Leucaena leucocephala (Lam.) de Wit. R Bras Zootec. 29: 387-391.

Valente TNP, Lima ES, Gomes DI, Santos WBR, Cesário AS, Santos SC (2016) Anatomical differences among forage with respect to nutrient availability for ruminants in the tropics: A review. Afr J Agric Res. 18: 1585-1592.

Vange T, Ikyeleve F, Okoh JO (2016) Effect of packaging materials and storage condition on soybean germination and seedling vigour in Makurdi. Res J Seed Sci. 9: 1-4.
Walker KP (2012) Fodder potential of leaves and pods of planted Leucaena diversifolia and L. leucocephala species in semiarid Botswana. Int Res J Agric Sci Soil Sci. 2: 445450.

Xavier SA, Fukami J, Miotto LCV, Sobottka RP, Nakatani SH, Takahashi LSA, Machado MH (2012) Dormancy break in seeds of Cupressus/usitanica Mill. Semina: Ci Agrárias. 33: 1041-1046.

Yu Y, Baskin JM, Baskin CC, Tang Y, Cao M (2008) Ecology of seed germination of eight non-pioneer tree species from a tropical seasonal rain forest in southwest China. Plant Ecol. 197: 1-16.

Zimmer G, Koch F, Carvalho IR, Szareski VJ, Demari GH, Nardino M, Follmann DN, Souza VQ, Aumonde TZ, Pedó T (2016) Seed quality and initial performance of seedlings of soybean produced off-season in Rio Grande do Sul, Brazil. Int J Curr Res. 8: 40325-40329. 